\title{
Where in the New Literary World Are We?
}

\author{
Af Margaret Mackey
}

\begin{abstract}
Da salget af e-bøger er fordoblet i løbet af blot seks måneder i USA og Amazon nu scelger flere elektroniske bøger end papirudgaver, er det tid til at gøre status over hvor vi er og hvor vi er på vej hen på bogområdet. Det vrimler med geografiske metaforer i dette "territorium", men det er tydeligt at vi noermer os et skelsattende øjeblik, som kalder på en vurdering af implikationerne ved vores nuvarende situation. Denne artikel, der trakker på udviklingen $i$ Canada og globalt, kortlogger det littercere landskab anno 2011. Hvor langt er vi kommet i retning af elektronisk laesning, og hvilke aktuelle udfordringer vil laeserne også stå overfor i fremtiden? Denne artikel leverer et øjebliksbillede af den aktuelle situation, vurderer betydningen af en rakke aktuelle forandringer og udforsker konsekvenserne for vores fremtidige loesevaner.
\end{abstract}

\section{Introduction}

Geographic metaphors are cheap and plentiful in the new literary landscape.

For example: we are approaching a watershed, as e-book sales outstrip paper book sales on Amazon. "Since April 1 [2011], Amazon sold 105 books for its Kindle e-reader for every 100 hardcover and paperback books, including books without Kindle versions and excluding free e-books," the New York Times reported on May 19, 2011 (Miller \& Bosman, 2011, n.pag.). In the United Kingdom, consumer digital sales soared by more than $300 \%$ in 2010 (Jones, May 3, 2011, n.pag.). E-book ownership in the United States doubled between November 2010 and May 2011, from 6\% to $12 \%$ of all US adults (Bookseller Staff, June 28, 2011, n.pag.) English-language e-book sales in markets where English is not the first language went up 300\% in 2011, with South Africa registering an increase of $432 \%$ and Sweden, $359 \%$ (Jones, October 12, 2011, n.pag.).

Not only is the landscape new, we are not even sure we can trust our compass. Contradictory evidence surrounds us. Even as Kindle texts outstrip their paper counterparts on Amazon, a study explores the behaviours of 39 first-year graduate students in computing science and engineering - who might be presumed to be early adopters. These students were issued with a Kindle DX, the largest version, for their academic work in return for having their behaviour investigated.
Margaret Mackey, Professor at University of Alberta, Canada(margaret.mackey@ualberta.ca) 
Seven months into the study, more than 60 percent of the students had stopped using their Kindle regularly for academic reading. ... O Of the students who continued to use the device, some read near a computer so they could look up references or do other tasks that were easier to do on a computer. Others tucked a sheet of paper into the case so they could write notes (Dudley, 2011, n.pag.).

We do not know what kinds of books people are buying for their Kindles from Amazon, but the University of Washington study suggests that the e-reader does not support some of the activities that comprise what we might call "serious" reading. It was difficult for the Kindle-wielding students to skim an article prior to reading it, and the device did not support cognitive mapping, "in which readers used physical cues, such as the location on the page and the position in the book to find a section of text or even to help retain and recall the information they had read" (Dudley, 2011, n.pag.).

We are rushing along so pell-mell into this landscape of metamorphosis that it is hard to pause long enough to catch our breath, let alone sum up the gist of how we understand the changes so far. In this article, I will explore the new territory largely by resorting to snapshots and sketch maps, rather than rigorous scientific study. There is an important place for empirical research but it is, by its very nature, time-consuming and therefore retrospective in its impact. On this occasion, which is strongly marked by high-speed change, I am interested in raising questions about where we are now, rather than presenting a carefully researched account of the implications of where we were even recently.

The hypothesis that sustains my exploration is that we are watching a cultural development with revolutionary potential. We have seen several such scenarios in the past two decades involving, for example, Napster, DVDs with all their extra tracks, texting, or Facebook and other social media. We know how swiftly the cultural landscape can shift. For a long time, however, it seemed as if sustained reading would resist the electronic tsunami, as if the many virtues of paper and the codex would hold steady against digital encroachments. Over the months of 2011, however, that stance has steadily become less sustainable. It does begin to appear that many forms of reading, not just the information-seeking vari- ety, are heading in an electronic direction. What will this development mean, both for readers and also for those who seek to understand reading behaviours?

I first used an electronic book with research participants in 1999 (Mackey 2007/2002); the 10- and 13year olds who explored the potential of my clunky Rocket E-Book were less than impressed. A few years later I gave a Sony E-Reader to a group of adults (Mackey 2007); they too were underwhelmed and many of them proclaimed their attachment to paper. Yet I suspect that if I could trace these participants today, I would find many of them owning a Kindle or a Kobo, or reading on their mobile phones. We are in the middle of a radical shift, of the kind that often leads to permanent change. Suddenly, the e-book looks like a serious competitor to the centuries-old technology of the codex.

I propose, therefore, to rough out as contemporary a map as possible - not a predictive outline of where we are going, because we really don't know, but a sketch map of what we understand about where we have gone so far. Many of my landmarks will be Canadian, since that is where I am standing myself, but I will endeavour to include more global examples where I can. In any case, Canadian readers will supply a robust set of examples that will ground a more general discussion of a changing landscape. I hope that outlining some of the changes in the territory we call reading will help us to gain our bearings, at least for a moment, in a time of rapid change. The nature of such a reconnaissance is that it will be out of date almost at once, but even gaining some sense of "this is where we were in late 2011 " may help to clarify our thinking. In the second part of this paper, I will consider some implications of current changes.

\section{Part I}

If we want to sustain the geographic motif, then my headings in the following section represent some major landmarks: general observations that seem to me to be important in 2011 and that have some resonance for the future.

\section{Paper is not dead}

A 2011 Canadian survey of book use provides some significant numbers that illuminate the nature of the 
digital revolution and the contemporary role of the analogue.

Roughly 34 million Canadians, in the week of January 10-16, 2011, purchased and borrowed rather more than 2,714,946 books, buying more than 1,110,586 books in English and French, and borrowing more than 1,604,378 from libraries. All the numbers are underestimates, of course. The survey of purchases did not include any data about digital downloads, but the library survey indicated that about $2 \%$ of borrowing was in electronic form (something over 30,000 books) (Medley, 2011, n.pag.).

The numbers testify to a dynamic reading world in Canada. The data collection methods mean that the total number is definitely an under-estimate. The high proportion of bought to borrowed books indicates a population used to owning what it reads and in charge of a reasonable amount of discretionary income. This tally certainly under-estimates the proportion of digital reading, but it is clear that any numbers that might be ascertained for e-reading and online reading would stand on the shoulders of a solid paper infrastructure.

These assumptions are reinforced by information from the Canadian publishing industry. Over the first ten years of the $21^{\text {st }}$ century, Canadian publishers produced 233,747 Canadian titles, with annual numbers increasing by $25 \%$ over the course of the decade. In 2010 alone, 28,624 titles were published - this in a country that also imports many additional books from the much larger countries that publish in the same languages (Barber, 2011, A15). It seems likely that it will take a long time before e-books can offer anything approaching the same range and variety of materials as are currently available in paper form, in Canada or elsewhere.

Canada is not alone in its enthusiasm for paper reading. The Bookseller in the United Kingdom reports that the top 1,000 titles in British libraries were loaned out more than 40 million times in 2010 (Jones, Jan. 22, 2011, n.pag.). Again, these numbers refer to hard copy loans only; digital reading involves still further numbers.

Are we seeing the last flourish of a dying habit? Or will the codex find ways to continue to co-exist with its e-competitors? The next five years will give us a lot to think about.

\section{Reading also occurs and is supported in more hy- brid ways}

As new possibilities multiply, paper is no longer the only available or convenient option. Contemporary readers are discovering new possibilities for blended and hybrid forms of reading, and lively debates address issues concerning new forms of exchange.

Different forms of access to online reading are surging, especially as mobile smart technology becomes ever more ubiquitous. Canadians are at the forefront of online reading, according to a comScore tally for the final quarter of 2010, reported in Canada Digital Year in Review 2010. Over that three-month period, leading the 11 countries surveyed in most categories, nearly 23 million unique Canadian users made an average of 95 visits online, spending 43 hours in which they looked at 3,349 pages (http://bassem-ghali.com/ search-engine-optimization/comscore-2010-canada-1216.html, accessed June 18, 2011).

Presumably these online reading hours must be added to however many hours Canadians spent in those last three months of 2010 reading the paper books they had bought and borrowed - not to mention their time with newspapers and magazines. It is not clear whether comScore would consider the reading of text messages as an online reading behaviour to be included in the numbers cited above. If not, then many more hours must be added to the notional totals we are accumulating.

As other media mutate, so reading is also added to activities that formerly excluded it; Samsung, for example, is producing something called "Social TV":

"It lets people view their Twitter and Facebook feeds on the side of the display beside the show they're watching. Should you want to join the conversation, a dual-sided Bluetooth remote sports a full QWERTY keyboard on the back. What's the point? When James Franco hosted the Oscars this spring, he pumped out plenty of juicy behind-thescenes tweets from backstage. With Social TV, users would be able to follow all of his updates without needing to check their phones, tablets or 
laptops. Hence the potential to enhance live programming." (Sapieha, 2011, B2).

This example may seem frivolous, but it will not be long before artists find ways to make more dynamic use of such affordances. Imagine a complex television series (such as The Wire, say) enriched by simultaneous viewer access to private tweets between characters, or in-character websites. The potential for a mixed-media extravaganza of great interest and subtlety, perhaps involving audience participation as well, is surely on the horizon.

Viewing and listening are becoming more integrated with reading in other ways as well, especially in the rapidly proliferating world of textual apps for mobile phones and tablets such as the iPad. We are just at the beginning of the exploration of ways in which electronic reading can mutate into a more multimodal activity. Electronic books can already come with soundtracks, animations, video enhancements, and/ or live links to the internet and telephone voicemails; more interactive developments are not far away. Small children are already very comfortable with this technology and baby book apps represent a growing market.

Ironically, though, e-reading is simultaneously heading away from glitz and extra features. Reading words on a regular Kindle can be a more monomodal experience than reading the same words on a paper page. The elements of graphic design that have long been a feature of the page are much reduced in the standard Kindle format. White space is evacuated as the words fill the screen from one side to the other. Elegance of font often gives way to something more predictable that can be increased or reduced in size. Paper quality ceases to be a factor of the reading experience. A page of one book often looks remarkably like a page from another. It remains to be seen if such drab efficiency remains a hallmark of most e-reading or if, for example, the new Kindle Fire will restore significant components of design to the ereading screen.

As reading itself develops in varying ways, so does the institutional promotion of reading. Such promotion occurs in various ways, some related to recreational reading and some to classroom assignments. How can activities that support reading make best use of a new hybrid environment?

\section{Supporting recreational reading}

In terms of reading for pleasure, a Canadian example offers an idea of how scaffolding for recreational reading is mutating. The Canadian Broadcasting Corporation's nation-wide program Canada Reads offers a variety of portals. This project involves the promotion of five Canadian titles, eventually narrowed down to just one winner through a process of radio discussion. The longlist is chosen through a process of online and social media nomination and lobbying, followed by online voting. A group of experts creates the shortlist of five titles out of this longlist. A celebrity advocate is assigned to each book and a heavily promoted radio program on the Canadian Broadcasting Corporation allows each to defend his or her title until a winner is finally decided. 1.75 million people listen to this radio program; a further quarter of a million listen to it in podcast form. The winning book generally sells somewhere between 30,000 and 80,000 more paper copies than might otherwise be expected (Taylor, 2011, n.pag.).

In this elaborate process we see a mix of digital and analogue, computers, mobile telephones, the old medium of radio, the new medium of podcast, and a culminating impact on the sales of paper books.

Similarly the British scheme for shadowing the Carnegie Medal deliberations allows young readers mixed formats of scaffolding for their reading as they assess the contenders for the prize. At the end of June 2011, just after the winners were announced, the website featured over 12,000 reviews of shortlisted books, written by young readers (http://www.carnegiegreenaway.org.uk/shadowingsite, accessed June 27, 2011).

There are other kinds of hybrids of paper and online reading, of course. Fan fiction supplies one major example of how paper reading and online reading may flow back and forth. Other, more formal relationships are being established regularly, many of them aimed at classroom study of literature. How should teachers be supported as they address students whose out-ofschool reading involves an ever-widening variety of format and purpose?

\section{Supporting the study of literature}

Two sample support sites offer a range of perspectives on a book and on the experience of reading it. The Literature Network, for example, offers a blend of respectful background information to buttress the 
reading of "classic" print literature and a mélange of more contemporary materials. To stick to my Canadian theme, I looked up L.M. Montgomery, author of Anne of Green Gables and many other titles (http:// www.online-literature.com/lucy montgomery/, accessed June 4, 2011). The material on Montgomery represents a broader online literature pedagogy in many ways. On the Montgomery home page, when I first look at it, there are six banner advertisements. To an eye accustomed to reading from the book page, the screen page seems saturated with distractions.

A small photograph of Montgomery and a relatively lengthy biography are supplemented by a list of all her novels. There are also links to three other pages: related links and articles, quizzes, and forum discussions. The related links page, itself spattered with many more advertisements, offers a connection for locating essays about Montgomery, but clicking on that link simply leads to a generic essay mill, which makes the following promises:

"Welcome to The Essay Archive! We have over 35,000 essays, term papers, and book reports in our humongous essay archive on thousands of topics. Don't believe the hype of other termpaper sites that charge $\$ 10$ a page for a paper that you are not even allowed to turn in! Join The Essay Archive and get access to all our essays for one low fee." (http:// www.essayarchive.com/, emphasis in original, accessed June 4, 2011).

The place of the essay mill in our map of the contemporary reading landscape deserves some further attention. Like some analogue counterparts unfortunately all too familiar in the literature classroom, the essay mill announces that the least important part of reading is the pleasure of actually doing it. Students search the Internet for essay fodder; their teachers feed that verbiage straight back into the Internet in hopes of catching the cheaters through keyword searches. It is a demoralizing evisceration of process in favour of the bulk creation, distribution and assessment of product.

The discussion forum available for Montgomery is disappointingly slight, but there is clearly a move on this website to envisage a pedagogy that makes room for at least some of the potential of the digital to allow readers to mark up, talk back, rethink, and so forth - as well as a nod to the worst kind of essaymill cheating. It represents an intriguing mix.

A different literature support site is teachingbooks. net. Again I looked up L.M. Montgomery. I signed on using my email address and, within minutes, the site had responded with an introductory email to me.

Although some of the links on teachingbooks.net were fresh and interesting, I felt a pang of analogue recognition (and not in a good way!) when I discovered the teachers' guides. Here is one example (readers are instructed to answer all questions in complete sentences, it hardly needs to be said):

"Chapter 1 - Mrs. Rachel Lynde Is Surprised

1 . Who is telling the story?

2. How does L.M. Montgomery compare use [sic]

a stream to describe Rachel Lynde's character?

3. Briefly describe Matthew's character?

4. Why is Rachel so interested in Matthew's behaviour?

5. What caused Rachel to be stricken dumb for five seconds? (page 6)

6. How does Rachel feel about Marilla's decision?

Vocabulary: traversed, ferreted, decorum, gauntlet, innovation, qualms, uncanny, profound.

Enrichment: Give evidence of Marilla's very blatant racism in the first chapter. Today we would consider these comments repulsive. Would Marilla's behaviour have been more acceptable in the time period that this novel was written? Have you ever experienced any form of racism? How did you deal with it?" (Thornton, 1997, n.pag.).

This approach to the book combines a dull form of regurgitation and paraphrase and the usual highly miscellaneous and unrelated vocabulary work, together with a very bossy leap into telling readers how to respond to the story and a huge leap out of the narrative into very personal territory indeed. Readers are barely given a moment to become engaged with the story before they are being bounced into anachronistic rejection of a major character.

To be fair to teachingbooks.net, it also supplies links to more interesting sites, particularly that of the L.M. Montgomery Institute, which supplied very current information and suggestions (one link put me 
through to a British newspaper article published that very day; it is hard to imagine how it could be more up to date).

But a teacher hoping to acknowledge the huge changes in reading structures and to enrich classroom experience with online augmentation would have to pick and choose very carefully in order to avoid a simple re-run of the worst of analogue comprehension exercises or the deep cynicism about reading and learning that is entailed in the essay mills. For every element of a brave new world online, there are aspects of the cowardly old world simply digitized and re-issued. Are other forms of online reading support more constructive and innovative? How do teachers shed the backwards-looking impact of the same old and tired wine disguised in new digital bottles?

\section{New forms of literary play and work are flou- rishing}

It depresses me that I am so often depressed by teaching sites, but they are not a reason to disregard the potential of the Internet altogether. Other sites are more playful and imaginative. For example, Google Lit Trips (googlelittrips.com, accessed June 5, 2011) marries certain books with the affordances of Google Earth, so the geography of a story is overlaid on the Google image of the world. You can zoom into a relevant Google street scene or trace the wanderings of a character across the globe, complete with added information items and photographs. It is a bit schematic and I did not find any discussion of the fault-line between the fictional creation and the real-world setting (which is not to say that the site does not contain such a discussion somewhere - one of the important aspects of a digital construct, to which we pay far too little attention, is that we can almost never be sure we have seen all of it). Nevertheless, even with a relatively high quotient of didacticism in some entries, it supplies a sense of gaming that is a long way from earnest comprehension questions.

A different approach again comes from BookRiffs. com, which sets up a business model that allows readers to create a verbal equivalent of the old music "mix tapes" that ardent music lovers used to create with their tape recorders. BookRiff"s frame structure is plainly commercial but it does incorporate a genuine component of absorbed reading: the wish to col- late the wisdom and delight of books. As far back as the eighteenth century, readers copied favorite passages into commonplace books, sometimes adding their own annotations; BookRiff's digital approach makes the process simpler and slicker - and perhaps marketable! Here is their introduction:

"Build your own books.

With BookRiff ${ }^{\mathrm{TM}}$, you can create books by mixing content from virtually any source: published books, your own files, web sites... you name it. You pick the mix and the order, \& we'll deliver your custom book - digital or printed - to you and anyone else!

Sell your content.

BookRiff's ${ }^{\mathrm{TM}}$ simple business model makes it easy for anyone, from publishers to authors and other individuals, to sell their works as content pieces that other users can include in Riffs ${ }^{\mathrm{TM}}$." (http:// bookriff.com/, accessed June 5, 2011).

"BookRiff also offers a tool for managing the the considerations of intellectual property that dog so much of our contemporary reading lives:

Each time a Riff is distributed, all content owners and contributors get paid. BookRiff's technology manages the authoring, bundling, licensing, attribution and payment details for each of these custom compilations. That's pretty powerful!" (http:// bookriff.com/, accessed June 5, 2011).

BookRiff is a single example; there are many other online offers of ways to enhance your reading and an exhaustive survey would probably be completely impossible.

Fan activity enhances and extends the pleasures of reading in less commercial ways; indeed it sometimes challenges the commercial grip of the big corporations. It is clear that many readers take playfulness as a reading right, and engage with each other as they create their fan responses. How else does reading become more social as online affordances increase in importance?

\section{The line between private and public response is blurring}

As our reading options expand, new forms of saving, organizing, and storing our own personal reading metadata are ever on the increase. Such web manag- 
ers as delicious.com and Library Thing provide us with prodigious organizing powers to marshall what we have read, what we want to read, what we own already, what we have borrowed, what we might like to own or borrow, and so forth. Such sites also allow us to share our forms of organization with others. We can add tags and create folksonomies that allow unknown others to access our literary lives.

Sites such as Amazon also allow us to share our responses to particular books, and many public libraries are moving towards forms of social cataloguing. Being able to sample professional and lay reviews at the point of purchase, all conveniently located in one place, has become an important part of many people's book selection strategies. The usual caveats apply, of course; Amazon's open structure means that it is relatively easy to flood the system with reviews favouring a particular judgment. Nevertheless, the conversation about a particular book that may be conducted on the Amazon site offers something new to today's readers.

The e-reader Kobo is experimenting with social reading in different ways, making links to Facebook. A press release from Kobo explains:

"Kobo, a global leader in eReading with 4.9 million users worldwide, today announced Kobo Pulse тM, expanding its social platform - Reading Life and its leadership in social e-Reading. With Kobo, every page of every book has a pulse - an indicator of social engagement driven by who and how many people are reading, what they are saying, and what they are thinking. Kobo Pulse (TM) allow readers to learn about the life of a book, connect with friends, share their sentiments, and engage in thought provoking discussions while reading any book. Kobo Pulse and your Reading Life are also integrated with Facebook." (Biba, 2011, n.pag.).

Kobo makes connections possible but it is not clear that they have resolved one of the unarguable commitments of sustained reading: you can either be reading or you can be discussing your reading, but you cannot be doing both at the same time, no matter how glibly Kobo makes use of the word "while" in their press release. Nevertheless, this development has the potential to open up reading experiences to a more collective overall approach. Whether readers are interested in such features as "feeling the life" of a book through indicators of the intensity of other people's social engagement recorded on the Pulse feature - or whether they simply want to keep reading - is a question that remains to be answered. A pessimist might consider that opening up sustained reading to the kinds of distraction that dog much of our lives in other arenas is a debatable form of progress.

In more extensive ways, bloggers speak about reading to other readers, or speak about supporting readers to other professionals. Here a more complex conversation becomes possible.

One risk of this lavish supply of supports, of course, is the old problem that you can spend all your time reading about reading, reading about organizing and/or posting lists of your reading material, reading about how hard it is to find time to read, and so forth - reducing your time for actual reading almost to the vanishing point. Presumably at least some of this shared digital surround-sound of commentary builds from or leads to a solid base of reading, but it sometimes seems as if the time-consuming activity of sustained reading might be lost in all the buzz of private and social activity. How might it be possible for researchers to monitor the survival of intense and continuous reading in the face of this new turn to the social?

\section{The global picture is more complex than we some- times think}

The digital divide is a much more complicated matter it might seem at first glance, and this is probably even more true globally than it is locally. Issues of ownership and issues of access are readily muddled and it is easy to resort to stereotypes. A dedicated e-reader is not essential for e-reading, and the mobile phone's role in changing habits and possibilities needs to be monitored attentively, given that the spread of mobile phones is truly, if differentially, global. How can the world-wide impact of the mobile on reading activities be monitored realistically?

\section{Part II}

My verbal sketch map is rough and ready but it certainly gives us plenty to think about. In what kinds of terms should we consider the future of reading? 
What changes and what remains the same - and in what conditions?

One way of thinking about e-reading is simply as just another way to read a book. In this scenario, we can merge the figures for reading on paper and reading electronically. We may think of e-reading as a more or less invisible substitute for paper reading; what was once read on paper is now read on a screen. The e-book represents a threat to the mass-market paperback, perhaps, but the act of reading carries on regardless.

Is such a seamless substitute possible? Does the electronic form change reading in significant and/or irrevocable ways? Do we actually belittle the potential of e-reading by considering it only in the context of paper reading? Do changing conditions of ownership and access change reading itself?

Certainly some of the social conditions of reading are different with an e-book. On the face of it, your reading becomes much more private. Nobody knows what is on your screen. Teenagers in particular often value such anonymity. But at the same time, while the people around you have less idea about what you are reading, the e-bookseller possesses comprehensive and permanent records of your buying history in ways that are nowhere near as possible in the analogue world of paper purchases in physical bookstores. Amazon goes further and tracks some of your reading behaviour, according to Sue Halpern in The New York Review of Books:

“Even reading devices like Amazon's Kindle pay attention to what users are doing: highlight a passage in a Kindle book and the passage is sent back to Amazon. Clearly, the potential for privacy and other civil liberty abuses here is vast." (2011, n.pag.).

Some readers suggest that they read more on their e-book because of the ease of ordering - they come to the end of one book and its sequel is only a click away. At the same time, however, Jakob Nielsen, in a small study, suggests that e-reading is slower (2010, n.pag.) It will be interesting to see if reading speed increases as readers get more accustomed to the screen, and also as e-ink comes closer to emulating the contrast values of ink on paper. Nielsen's project raises more questions than it answers but it is suggestive for future research.

Speed is one issue; distraction is another. Even on the dedicated e-readers, where the delights of the web are less freely available than on computers and tablets and phones, the ease of abandoning one text to click to another can be quite seductive. We need to know a great deal more than we do about e-reading "in the wild," so to speak, in people's recreational usage, to get some sense of the degree to which intense deep reading is surviving in electronic modes. Ethnographic and longitudinal studies to consider all these issues are essential.

But as we speculate about the future of digital reading, we have other models to assist our thinking. If we look to the model of e-music, we can anticipate more sampling and more making collections of samples (along the lines of BookRiff or in other ways). We can expect more swapping, either of samples or of full texts, as the e-purveyors bow to public pressure and make private e-lending more straightforward. Readers will find it easier to share tastes and titles.

If we take contemporary television as our model, we may find that there is more socializing around reading. Like TV viewers, readers may chat to each other before, "during" (that is, before they have come to the end of the text; as I have spelled out above, the limits of human attention do not allow a person to read and chat simultaneously), and after their reading. They may even acquire a taste for "speaking back" to authors and publishers, as occurs on many sites related to particular television shows. As the framework for reading becomes more social, we may even see books that "shout out" to fans in a variety of ways.

Print literature is already susceptible to fan re-rendering, every bit as much as its electronic counterparts; what Peter Lunenfeld calls "the universal solvent of the digital" $(1999,14)$ has unpackaged the determinate ending of the print story and laid it open to fan re-interpretation. It may be that reading electronically makes us more likely to click through to fanauthored alternatives as the book becomes unbound, so to speak. 
Do online conversations count as "more" reading? It depends on who gets to make the assessment. There is no question that contemporary young people are engaging in enormous quantities of one particular kind of reading and writing in their constant texting. But these young people and their parents alike are ambivalent about whether such activities really count as reading (2010 The Kids \& Family Reading Report, n.pag.).

How we think about texting and other forms of small-screen engagement actually makes a big difference to how we rate questions about contemporary reading. Texting is only one aspect of smart phone use:

"Surveying users between the ages of 15 and 24 in countries including the United States, China, Italy, the United Kingdom, and Saudi Arabia, Nielsen found young people in Saudi Arabia are more likely to be tapping away to grab a screen saver, while in China they're probably downloading a ringtone." (Barack, 2011, n.pag.).

Are texting and tweeting forms of reading and writing? Or are they simply ways of playing with the affordances of the mobile screen in an activity of selfpresentation equivalent to selecting screen savers and ringtones, harmless but not offering much intellectual nourishment? There are many ways of answering these questions; what is the most constructive approach?

The more things change...

Exposure to sophisticated activities is not necessarily a shortcut to true sophistication. The Scholastic report on young people and their families presented this very sobering statistic: $39 \%$ of Americans aged between 9 and 17 agreed with this statement: "The information I find online is always correct" (2010 The Kids \& Family Reading Report). Clearly basic work on critical literacy needs to remain an important priority.

There are also other major questions about the degree to which recreational literacies and schooled literacies inter-connect. A comparison of two small, intense studies of teenage readers makes a disturbing point. As long ago as 1964, way before any digital changes had begun to affect how we read, James Squire investigated the responses of 52 ninth and tenth grade students as they read four short stories. Developing an intense qualitative and quantitative analysis of these responses, he found a high reliance on stock reactions. He also uncovered what he called "happiness binding" $(1964,41)$, a determination to read a sentimental optimism into even sad and unpleasant story scenarios. This tendency played out in different ways. "Related to some of the other sources of difficulty but more subtle in effect," Squire found, "is the tendency of some readers to insist on clarity and definiteness in interpretation even when clues in the story are fragmentary and minimal" $(1964,47)$.

For all the decades of radical change in literary affordances, Susan Lee Groenke and Michelle Youngquist, writing in 2011, offer an eerily similar scenario when they describe contemporary ninth graders reading Monster by Walter Dean Myers. Monster presents its hero in highly ambivalent and indeterminate terms. These young readers struggled with it in ways that James Squire would probably recognize. Ironically they made use of social media to discuss the book on a chat tool in Moodle, yet MissPiNk was quick to opine, " $i$ think that the story is going to end happy" $(2011,510)$ - a line that could have come straight from Squire's study. They were also very determined to find a "message" in the story, and were quite prepared to over-ride the evidence in the text to do so, as this passage demonstrates. The readers have just learned that Steve lied in court.

"MissPiNk: yea but even though he lied he is not in jail and he will probly never do anything like that again cause he now knows what could happen MissPiNk: so he learned a lesson no matter what... Chill1: yeah, and he will make better choices in life. And not hang out with Bobo, and king Chill1: or people like that in general

LOL: yeah so i guess he just learned hs lesson that way and hopefully wont do it again." (2011, 511, spelling and punctuation as in original).

After all the statistics about the swift and enormous revolution in our textual lives, it is chastening to read the schooled responses of these young people, separated by almost five decades but alike in their determination to develop a simplistic interpretation of a subtle fiction. While educators grapple with the complexities of all the new formats, genres, and media, they must also still find ways of bringing young people around to more complex ways of thinking about 
what they read, wherever they find it and whatever vehicles they use to discuss it. We may be standing at a crossroads in our traversal of a newly developing global culture but some of the roads obviously lead backwards as well as forward.

At the same time, we may wonder if the expectations of these young readers might have been different, had they been reading electronically. I have no idea of what the answer to that question might be, but we now, when we consider issues of reading, need to take serious account of format. It is perfectly possible that some young people may have more conservative expectations of paper, may read stories on paper in ways that strike them as more orthodox. They may increase their anticipation of a restricted experience even more when the book is read in school. There are many questions for research to address.

As e-reading becomes more widespread, the tools for tracking its development will become more sophisticated. New data will begin to ground our queries about where we are now and where we are going and our maps will become more detailed and useful.

It is an exciting time but also a bewildering time. So much is changing, so fast, that the landscape sometimes appears completely unrecognizable. Yet we cannot take for granted that new technologies will automatically succeed in creating enthusiastic, skeptical, enlightened, and informed readers. As we check our compasses and re-draw our maps, much thinking, much rigorous research, and much careful teaching still remain a priority.

\section{References}

2010 The Kids \& Family Reading Report (2010). Scholastic: http://mediaroom.scholastic.com/kfrr

Barack, L (2011, February 3). "American Teens Average 3, 339 Texts a Month." School Library Journal: http://www.slj.com/slj/home/889103-12/american_teens_average_3339_texts.html.csp, accessed June 20, 2011.

Barber, J (2011, March 14). "Let's Shelve Our Protectionist CanLit Policy." Globe and Mail, A15.

Biba, P (2011, September 27). "Kobo Expands Reading Life with Facebook Integration.” TeleRead:
News \& Views on E-Books, Libraries, Publishing and Related Topics. http://www.teleread.com/paulbiba/kobo-expands-reading-life-with-facebook-integration/, accessed September 29, 2011.

Bookseller Staff (2011, June 28). "US E-Reader Ownership Doubles in Six Months." http://www. thebookseller.com/news/us-e-reader-ownership-doubles-six-months.html, accessed June 29, 2011.

Canada Digital Year in Review 2010 (2011, March). comScore: http://www.comscore.com/Press_Events/ Presentations_Whitepapers/2011/The_2010_Canada_Digital_Year_in_Review, accessed June 4, 2011.

Dudley, B (2011, May 2). "Kindle So-so for Students, UW Study Concludes." The Seattle Times: http://seattletimes.nwsource.com/html/technologybrierdudleysblog/2014937738_kindle_so-so_for_ students_uw_s.html, accessed June 3, 2011.

Groenke, SL \& Youngquist, M (2011, April). “Are We Postmodern Yet? Reading Monster with $21^{\text {st }}$. Century Ninth Graders." Journal of Adolescent \& Adult Literacy 54(7), 505-513.

Halpern, S (2011, June 23). "Mind Control \& the Internet." The New York Review of Books: http://www. nybooks.com/articles/archives/2011/jun/23/mindcontrol-and-internet/, accessed October 12, 2011.

Jones, P (2011, October 12). "English-language ebooks in global surge." The Bookseller.com: http:// www.thebookseller.com/news/english-language-ebooks-global-surbe.html, accessed October 12, 2011.

Jones, P (2011, May 3). "Digital Sales Now Worth $6 \%$ as E-books Grow 300\% in 2010." The Bookseller.com: http://www.thebookseller.com/news/digitalsales-now-worth-6-e-books-grow-300-2010.html, accessed June 3, 2011.

Jones, P (2011, January 22). "Top 1,000 Titles Loaned 40m Times in 2010." The Bookseller Morning Briefing.

Lunenfeld, P (1999). The Digital Dialectic: New Essays on New Media. Cambridge, MA: MIT Press. 
Mackey, M (2007). Mapping Recreational Literacies: Contemporary Adults at Play. New York: Peter Lang.

Mackey, M (2007/2002). Literacies across Media: Playing the Text. Rev.ed. London: Routledge.

Medley, M (2011, January 19). "National Book Count Numbers Are In: Canadians Purchase/Borrow 2.7 Million Books." National Post: http://arts.nationalpost.com/2011/01/19/national-book-count-numbers-are-in-canadians-purchaseborrow-2-7-millionbooks/, accessed June 20, 2011.

Miller, CC \& Bosman, J (2011, May 19). "EBooks Outsell Print Books at Amazon." New York Times: http://www.nytimes.com/2011/05/20/ technology/20amazon.html?_r=1\&sq=amazon sales $\& s t=c s e \& s c p=1 \&$ pagewanted $=$ print, accessed June 3, 2011.

Nielsen, J (2010, July 2). "iPad and Kindle Reading Speeds." Alertbox: http://www.useit.com/alertbox/ ipad-kindle-reading.html, accessed June 19, 2011.
Sapieha, C (2011, June 18). "Twitter on TV? Samsung Has an App for That.” Globe and Mail, B2.

Squire, JR (1964). The Responses of Adolescents While Reading Four Short Stories. NCTE Research Report No. 2. Champaign, IL: National Council of Teachers of English.

Taylor, K (2011, February 7). "This year, more than ever, Canada Reads is the people's choice." Globe and Mail: http://www.theglobeandmail.com/news/ arts/books/this-year-more-than-ever-canada-readsis-the-peoples-choice/article1897103/, accessed June 30, 2011.

Thornton, B (1997). Study Guide to Anne of Green Gables. Cape Creations: http://www.teachingbooks. net/agr.cgi?url_id $=739 \& r=1 \&$ ri $=553$, accessed June 5, 2011 . 